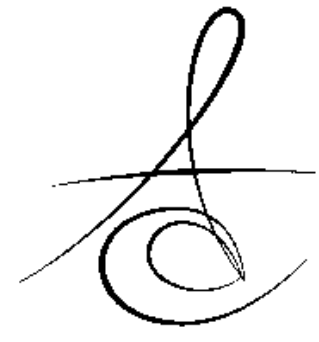

Makale Kodu/Article code: 2564

Makale Gönderilme tarihi: 22.01 .2016

Kabul Tarihi; 22.08.2016

\title{
COMBINED ESTHETIC THERAPY OF SEVERE DENTAL FLUOROSIS: A CASE REPORT
}

\section{ŞİDDETLİ DENTAL FLOROZİSİN KOMBİNE ESTETİK ESTETİK TEDAVİSİ: BİR OLGU SUNUMU}

\author{
Uzm. Dt. Burcu GÖZETİi̇ ${ }^{*}$ \\ Yrd. Doç. Dr. Mahmut KUŞDEMİR**
}

Yrd. Doç. Dr. Funda ÖZTÜRK BOZKURT**

\section{ABSTRACT}

In todays' modern dentistry, the undesirable appearence of dental fluorosis need to be improved to satisfy patients' esthetic requirements in a minimally invasive manner. The approach proposed for the treatment should remove the stained enamel defects, provide blending effect for chalky white appearence and strengthen the enamel against caries development. The purpose of this case report is to present the clinical results of a combined esthetic treatment of a severe fluorosis case with microabrasion, bleaching and resin infiltration.

Treatment plan was based on a combined approach of microabrasion, home bleaching and resin infiltration.

An improvement in the esthetic appearence was achieved and remained stable in the 6-months follow-up.

The technique might be more minimally invasive, less time consuming and cheaper compared to restorative techniques.

Key Words: dental fluorosis, microabrasion, home bleaching, resin infiltration

\section{ÖZET}

Günümüz modern diş hekimliğinde, hastaların estetik beklentilerini arttırmak için dental florozisin istenmeyen görüntüsünün minimal invaziv yaklaşımla iyileştirilmesi gerekmektedir. Tedavi için önerilen yaklaşım, renklenmiş mine defektlerini uzaklaştırmalı, beyaz tebeşirimsi görüntü için renk eşitleyci etki sağlamalı ve mineyi çürük gelişimine karşı güçlendirmelidir. Bu vaka raporunun amacl, şiddetli dental florozisin mikroabrazyon, beyazlatma ve rezin infiltrasyonu ile kombine estetik tedavisinin klinik sonuçlarını sunmaktır.

Tedavi planı, mikroabrazyon, ev tipi beyazlatma ve rezin infiltrasyonun kombine edildiği bir yaklaşıma dayanmaktadır. Estetik görüntüde bir iyileşme sağlanabilmiş ve 6 aylık takip süresince stabil kalmıştır. Restoratif teknikler ile karşılaştıııldığında, teknik daha minimal invaziv, daha az zaman gerektiren ve daha ucuz olabilir.

Anahtar Kelimeler: Dental florozis, mikroabrazyon, ev tipi beyazlatma, rezin infiltrasyon

\section{INTRODUCTION}

Dental fluorosis is a developmental disturbance caused by excessive fluoride ingestion during tooth formation ${ }^{1}$. The strong relationship between fluoride concentration in drinking water and the prevalence and severity of dental fluorosis were showed by Dean et $\mathrm{al}^{2,3}$. However, in recent years not only the fluoride in drinking water or diet but also the fluoride in dental products have been identified as being potentially responsible for the prevalence of dental fluorosis ${ }^{1,4}$. Even a small 'pea-sized 'amount of toothpaste containing $1450 \mathrm{ppm}$ fluoride would provide approximately $0.36-0.72 \mathrm{mg}$ fluoride, which if consumed twice a day could contribute to fluoride levels that would increase the risk of dental fluorosis in children ${ }^{5}$. Morover, fluoride that has been added to milk and salt in recent decades for its beneficial effects on prevention and control of dental caries, could lead to ingestion of excessive amounts of fluoride ${ }^{6}$.

\footnotetext{
${ }^{*}$ Specialty of Restorative Dentistry, Department of Restorative Dentistry, School of Dentistry

${ }^{* *}$ Department of Restorative Dentistry, School of Dentistry, İstanbul Medipol University
} 
According to many studies and reports up to date, fluorosis is still a serious public health problem affecting millions of people in the world especially in regions in which high concentrations of ionic fluoride have been found in ground waters ${ }^{1,4,6-8}$. Therefore an increasing number of patients with dental fluorosis are applying to dental clinics with esthetic expectations ${ }^{9}$.

The clinical manifestations of dental fluorosis depending on the dose and exposure time show variations. Thylstrup and Fejerskov Fluorosis Index (TFI) have been developed which is the expanded version of Dean's index to include: mild (TFI=1-3), moderate $(\mathrm{TFI}=4-5)$ and severe $(\mathrm{TFI}=6-9)^{10}$ levels. Mild cases are characterized by white opaque appearence due to increased porosity and many thin horizontal lines running along the perikymata while the moderate cases characterized by chalky white appearence and focal loss of outer enamel with yellow to light brown staining. In severe cases, in addition to chalky white appearence and discoloration, teeth can erupt with pits. Although teeth with mild dental fluorosis may be more resistant to dental decay, severely fluorosed teeth are more susceptible to caries most likely because of their irregular surface structure and loss of outer protective layer ${ }^{1,11}$.

The treatment plan for dental fluorosis depends on the severity of the disease ${ }^{9}$. From mild to severe cases; bleaching, microabrasion, esthetic veneers or composite restorations, prosthetic crowns or combinations of these were recommeded in the literature ${ }^{10}$. The ultimate purpose of all of these treatments was to satisfy the patient's esthetic requirements.

In modern dentistry, it has been widely accepted that maximum sound tooth structure should be preserved while maintaining esthetic improvement. Nowadays, crowning and veneering seems to be destructive and outmoded for the estethic correction of dental fluorosis ${ }^{9}$. Kirby Bodden and Haywood ${ }^{12}$ suggested macroabrasion combined with nightguard bleaching as an easier and time efficient technique that would produce the most favorable outcomes. In a contemporary publication, Wang et $\mathrm{al}^{9}$ proposed a resin infiltration technique following macroabrasion and microabrison combined with home bleaching therapy as a minimally invasive approach for the esthetic correction of a severe fluorosis case. Munoz et $\mathrm{al}^{13}$ preferred to apply the resin infiltration technique alone and the outcome of the treatment for a mild case was satisfying.

The ability of resins to penetrate into the porous lesion body of enamel lesions was described over 30 years $\mathrm{ago}^{14}$. Since then many investigations focused on resin infiltrants that could penetrate significantly deeper into porous lesion body of the incipient enamel lesion in order to arrest the progression of caries $^{15}$. Considering the porous structure of the fluorotic enamel, the material for caries infiltration seems to be applicable to those lesions either. The resin penetrates into the lesion body driven by capillary forces, so that it occludes the microporosities in the lesion body ${ }^{16}$. As a side effect, the resin infiltrant can also mask the chalky white appearance of the lesions and this 'side effect' will improve the esthetic appearence of mild to moderate fluorosis cases in a minimally invasive manner ${ }^{17}$.

This clinical case report describes the combined treatment of a severe fluorosis case by microabrasion, home bleaching and resin infiltration technique and shows its 6 months follow-up results.

\section{CASE REPORT}

28-year-old Iranian man referred to our dental clinic with a chief complaint of yellow to brown discoloration and defects on all his teeth. His statement that lots of people in the region he had born and lived during his childhood suffered from the same appearence of their teeth supported this diagnosis. The patient also had the knowledge that the drinking water in the region they had lived was responsible for staining of the teeth. Clinically prominent cloudy patchy brown stains, generalized opaque white appearence and areas of missing enamel on the smooth surfaces, pits and slight attrition on the occlusal surfaces were noted (Figures 1 and 2). The clinical presentation and past medical and dental histories were consistent with a diagnosis of level 7 fluorosis on the Thylstrup and Fejerskov scale ${ }^{10}$.

Treatment plan was based on a combined approach of microabrasion, home bleaching and resin infiltration for managing the enamel surface and periodontal scaling to improve gingival health.

First of all, in order to protect soft tissues from any damage of the microabrasion paste, a light-cured resin barrier (OpalDam Green, Ultradent Products Inc, 
UT, USA) and a lip\&cheek retractor (OptraGate, Ivoclar Vivadent Inc, NY, USA) were applied. Both patient and clinician wore protective glasses for protection of their eyes. Subsequently, a small amount of abrasive paste (Opalustre, Ultradent Products, UT, USA) was applied on the buccal surfaces of the teeth by a special rubber cap (Oralcups, Ultradent Products, UT, USA) with slight pressure during 120 seconds for each tooth according to manufacturer's instructions (Figure 3). After water rinsing and visual inspection, the procedure was repeated once more. The clinical view at the end of microabrasion was shown in Figure 4.

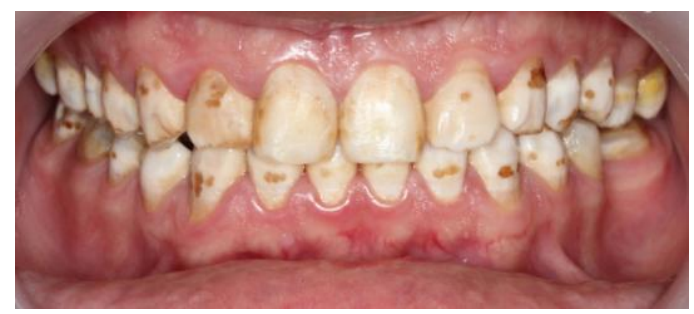

Figure 1. Clinically prominent cloudy patchy brown stains, generalized opaque white appearence and areas of missing enamel on the smooth surfaces

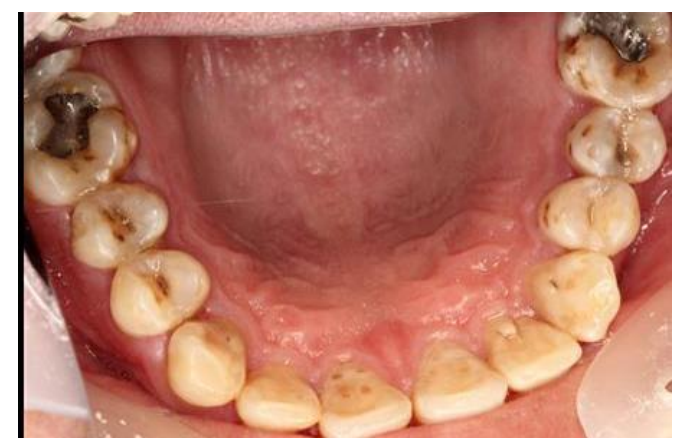

Figure 2. Pits and slight attrition on the occlusal surfaces

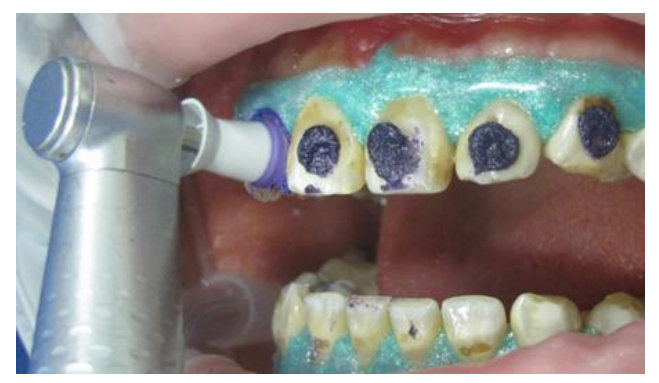

Figure 3. Application of abrasive paste

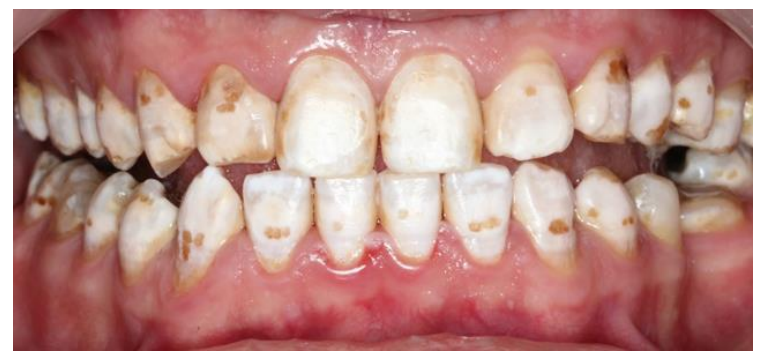

Figure 4. The clinical view at the end of microabrasion

The patient was informed about limitations during home bleaching. A $15 \%$ carbamide peroxide gel (Opalescence PF \%15 Ultradent Products, UT, USA) was dispensed for use according to standart protocols for two weeks to better harmonize color. At the end of 14 days bleaching therapy, the result was satisfying and the patient did not complain about any sensitivity. In order to improve resin-enamel bonding strength, resin infiltration procedure was delayed for two weeks ${ }^{18}$.

Resin infiltration technique includes three steps: first one is acid gel application (Icon-etch, DMG, Hamburg, Germany) composed of $15 \%$ hydrochloric acid, water, silica and additives; second one is ethanol (Icon-dry, DMG Hamburg, Germany) application and the last one is resin infiltrant application (Iconinfiltrant, DMG Hamburg, Germany) composed of tetraethylene glycol dimethacrylate, additives and initiators. A conventional rubber dam was applied to protect soft tissues and teeth were cleaned with prophylaxis paste to get rid of the dental plaque. After clean and dry working conditions were obtained, acid gel applied on the buccal surfaces of the teeth with the smooth surface tips included in the product kit. According to manufacturer's instructions acid gel was allowed to remain on the teeth surface for 2 minutes and then rinsed and air-dried. In this case acid gel application was repeated three times in sequence. When the acid etching procedure was completed, superficial discoloration and surface layer that could hamper resin penetration were removed ${ }^{19}$. Before resin application, ethanol was applied for 30 seconds and dried in order to remove the water retained within the microporosities of the lesion body. Subsequently, resin infiltrant was applied on the etched and dried surfaces with smooth surface-tips and allowed to penetrate for 3 minutes. Prior to light polymerization, excess resin was removed from the interdental spaces

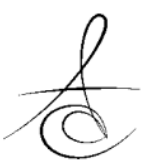


with the aid of dental floss. Following light curing for 40 seconds, resin infiltrant application was repeated once more, with a 1-minute time for penetration, as recommended. The entire infiltrated surface lesions were polished with discs (OptiDisc, KerrHawe SA, Bioggio, Switzerland) and proximal surfaces were polished with strips.

Consequently, an improvement in the esthetic appearence was achieved and remained stable during 6-months follow-up (Figure 5).

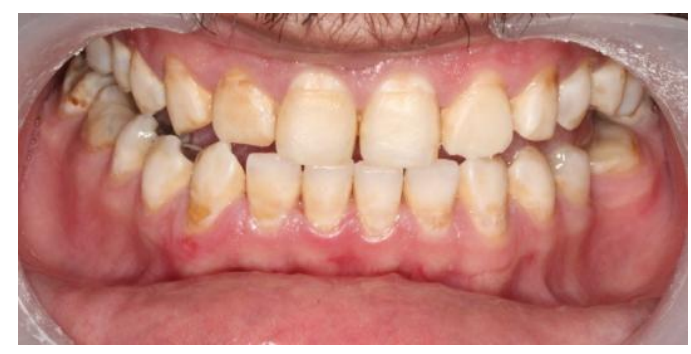

Figure 5. The clinical view after 6 months

\section{DISCUSSION}

The term dental florosis refers to developmental disturbance of enamel caused by the effect of excessive fluoride intake during tooth formation. The structural changes occur due to sensitivity of ameloblasts to high fluoride levels during the tooth enamel development that can be divided into 4 major stages: pre-secretory, secretory, transition and maturation stages ${ }^{1}$.

Matrix proteins disappear from nonfluorosed enamel in the maturation stage, but are retained in fluorosed enamel, as a result of decreased proteinase activity in a dose dependent manner ${ }^{1,20,21}$. Retention of amelogenin proteins can explain the clinically observed hypomineralisation and increased porosity of the fluorosed enamel. Although at higher levels of fluoride exposure, clinically, these hypomineralised areas might be thick opaque bands or patchy cloudy in appearence, at mild levels of fluoride exposure many thin hypomineralised horizontal lines followed by a hypermineralised band running along the perikyma- ta are observed ${ }^{1}$. The clinical manifestations of dental fluorosis vary depending on dose and duration of exposure during tooth development and treatment approaches vary depending on the severity of the dental fluorosis ${ }^{22}$.
The macroabrasion step which is recomended in the literature before microabrasion ${ }^{23}$ was skipped because the presence of enamel is important for treatments such as bleaching and resin infiltration, so even a small thickness of enamel was preserved and kept intact. Also, severely stained and defective structure was located beneath the equator line close to cervical area where the enamel thickness is very low and it is hard to perform a well controled macroabrasion at these areas.

Subsequent to microabrasion, home bleaching was performed to better harmonize tooth $\operatorname{color}^{24}$. Bleaching combined with microabrasion was first described by Archambault ${ }^{25}$ and since then it has been the recommended treatment approach for dental fluorosis in many publications ${ }^{12,25,26}$. Since the effects of 14 days of home bleaching with $15 \%$ carbamide peroxide were found to be superior than a single 1hour session of in-office bleaching with $30 \%$ hyrogen peroxide in the terms of color and luminosity ${ }^{27}$ home bleaching was preferred for this case.

The resin infiltration application following the bleaching combined with microabrasion is a novel approach for the esthetic improvement of dental fluorosis cases ${ }^{9}$. The involvements of resin infiltration might contribute to prevention of caries and masking the chalky white appearence. Resin infiltration concept aims to occlude the highly porous structures of incipient enamel lesions by means of low viscosity resins after the removal of superficial layer ${ }^{19}$. Similarly, fluorosed enamel includes areas of diffuse hypomineralization and porosities in the subsurface enamel ${ }^{9}$ and resin infiltration seems to be applicable for these lesions either. While the hypomineralized and porous structure of the fluorotic enamel lesions can be occluded with resin infiltrant, the penetration through the superfical enamel layer that is altered by microabrasion should be taken into consideration. Donly et $\mathrm{al}^{28}$ claimed that microabrasion alters the enamel surface to a higly polished, densely compacted, mineralized structure. This newly formed surface was tought to mask the subsurface stain and this is called "the abrosion effect ${ }^{28}$. Depending on the fact that acid etching procedure aims to remove the surface layer of incipient caries lesions which has a varying thickness of $40 \mu \mathrm{m}$ and mineral content of up to $82 \mathrm{vol} \%{ }^{19}$ it is possibly acceptable to apply acid etching to remove microabraded superficial enamel 
layer prior to resin infiltration. Further studies are required to specify acid etching procedure of microabraded superficial enamel layer.

The positive effect in masking the white spot lesions by resin infiltration technique has been showed in many in vitro/in vivo studies ${ }^{17,29}$. White spot lesions show an apparently intact surface which is followed by a more porous lesion body underneath and the increased porosity within the lesion body causes the whitish appearence of these lesions ${ }^{29}$. Indeed, light scattering at interfaces between substances of lesion body with different refractive indices (RI), like enamel/apatite (RI 1.62-1.65), water (1.33) or air (1.00), is responsible for the chalky white appearence of enamel lesions. ${ }^{[30]}$ When the watery medium or air in microporosities of lesions replaced by a resin infiltrant with a refractive index closer to apatite crystals (RI of infiltrant: 1.52), light scattering reduces, thus the esthetic appearence of opaque white lesions can be improved due to the blending effect ${ }^{17}$. In this case after microabrasion and bleaching, however the stains were removed, a whiter appearence was obtained and the resultant colour was satisfying for the patient, the remained whitish and brownish coloured patchy areas were still needed to be improved. Therefore the treatment completed with resin infiltration application that could provide the required masking effect to better harmonize teeth colour.

In addition to blending effect, the resin infiltration may also have beneficial effect on color stability. In an in vitro study, Paris et a ${ }^{17}$ showed that staining was significantly reduced for polished infiltrated white spot lesions compared to untreated or infiltrated unpolished lesions. Nevertheless, further studies are required that compare the long term color stability of severe dental flurosis cases in terms of the treatment approach with or without the involvement of resin infiltration.

\section{CONCLUSION}

Combination of microabrasion, bleaching and resin infiltration techniques for the treatment of a severe fluorosis case seems to be more minimally invasive, less time consuming and cheaper when compared to restorative techniques.

\section{REFERENCES}

1. DenBesten $P$, Li W. Chronic fluoride toxicity: Dental fluorosis. Monogr of Oral Sci 2011;22:81-96.

2. Dean HT, Jay P, Arnold FA, Elvove E. Domestic waters and dental caries. II. A study of 2832 white children ages of 12-14 years of eight suburban Chicago comunities, including Lactobacillus acidophilus studies of 1761 children. Public Health Rep 1941;56:761-92.

3. Dean HT, Arnold FA, Elvove E. Domestic waters and dental caries. V. Additional studies of the relation of fluoride domestic waters to dental caries in 4425 white children, age $12-14$ years of 13 cities in 4 states. Public Health Rep 1942;57: 1155-79.

4. Everett E.T. Fluoride's effects on the formation of teeth and bones, and the influence of genetics. J Dent Res 2011;90:552-60.

5. Institute of Medicine. Dietary reference intakes: for calcium, phosphorus, magnesium, vitamin D and fluoride. National Academies Press; Washington: 1997.

6. Ardu S, Stavridakis M, Krejci IA. Minimally invasive treatment of severe dental fluorosis. Quintessence Int 2007;38:455-8

7. Beltran-Aguilar ED, Barker LK, Canto MT, et al. Surveillance for dental caries, dental sealants, tooth retention, edentulism, and enamel fluorosisUnited States, 1988-1994 and 1999-2002. MMWR Surveill Summ. 2005;54:1-43.

8. State of art report on the extent of fluoride in drinking water and the resulting endemicity in India. Scientific and Technical Information Compilation for UNICEF, New Delhi by Fluorosis Research and Rural Development Foundation, New Delhi 1999.

9. Wang $Y$, Sa $Y$, Liang $S$, Jiang $T$. Minimally invasive treatment for esthetic management of severe dental fluorosis: A case report. Oper Dent 2013; 38:358-62

10. Thylstrup A, Fejerskov O, Mosha HJ. A polarized light and microradiographic study of enamel in human primary teeth from a high fluoride area. Arch Oral Biol. 1978;23:373-80.

11. National Academy of Sciences. Health Effects of Ingested Fluoride. https://www.nap. edu/read/ 2204/chapter/1 
12. Kirby Bodden M, Haywood B. Treatment of endemic fluororsis and tetracycline staining with macroabrasion and nightguard vital bleaching: A case report. Quintessence Int 2003;34:87-91.

13. Munoz MA, Arana-gordillo LA, Gomes GM, et al. Alternative management of fluororsis and hypolasia stains: Blending effect obtained with resin infiltration techniques. J Esthet Restor Dent 2013;25:32-9.

14. Robinson C, Hallsworth AS, Weatherell JA, Künzel W. Arrest and control of caries lesion: a study based on preliminary experiments with resorcinolformaldehyde resin. J Dent Res 1976;55:812-8.

15. Paris S, Meyer-Lueckel H. Inhibition of caries progression by resin infiltration in situ. Caries Res 2010;44:47-54.

16. Meyer-Lueckel $\mathrm{H}$, Paris $\mathrm{S}$. Improved resin infiltration of natural caries lesions. J Dent Res 2008;87:1112-6.

17. Paris S, Schwendicke F, Keltsch J, et al. Masking of white spot lesions by resin infiltration in vitro. JJOD 2013, www.intl.elsevierhealth.com/journals/jden

18. Haywood VB. History, safety and effectiveness of current bleaching techniques and applications of the nightguard vital bleaching technique. Quintessence Int 1992;23:471-88.

19. Kielbassa AM, Müller J, Gemhardt CR. Closing the gap betweenoral hygiene and minimally invasive dentistry: A review on the resin infiltration technique of incipient (proximal) enamel lesions. Quintessence Int 2009;40:663-81.

20. Zhou R, Zaki AE, Eisenmann DR. Morphometry and autoradiography of altered rat enamel protein processing due to chronic exposure to fluoride. Arch Oral Biol. 1996;41:739-47.

21. Lyaruu DM, Bervoets TJM, Bronckers ALJJ. Short exposure to high levels of fluoride induces stagedependent structural changes in ameloblasts and enamel mineralization. Eur J Oral Sci 2006;114. 1): 111-5

22. Akpata ES. Occurence and management of dental fluorosis. Int Dent J 2001;51:325-33.

23. Croll TP. Enamel microabrasion: The technique. Quintessence Int 1989;20:395-400.

24. Croll TP, Helpin ML. Enamel microabrasion: A new approach. J Esthet Dent 2000;12:64-71
25. Croll TP. Enamel microabarasion followed by dental bleaching: case reports. Quintessence Int 1992;23:317-21.

26. Cvitko E, Swift EJ, Denehy GE. Improved esthetic with a combined bleaching technique: case report. Quintessence Int 1992;23:91-3

27. Knösel M, Attin R, Becker K, Attin TA. Randomized CIE $L * a * b$ avaluation of external bleaching therapy effects on fluorotic enamel stains. Quintessence Int 2008;39:391-9.

28. Donly KJ, O'Neill M, Croll TP. Enamel microabrasion: a microscopic evaluation of the "abrosion effect". Ouintessence Int 1992;23:175-9.

29. Torres CRP, Borges AB, Torres LMS, Gomes IS, Oliveria RS. Effect of caries infiltration technique and fluordie therapy on the colour masking of white spot lesions. J Dent 2011;39:202-7

30. Meng $Z$, Yao XS, Yao $H$, Liang $Y$ and et al. Measurement of refractive index of human teeth optical coherence tomography. Journal of Biomedical Optics 2009;14:34010-4.

\author{
Yazışma Adresi \\ Burcu Gözetici, \\ İstanbul Medipol University, School of \\ Dentistry, Unkapanı, Atatürk Bulvarı, No:27 \\ Fatih-İstanbul-Turkey 34083 \\ phone: +905363283861 \\ E-mail: bgozetici@medipol.edu.tr
}

